Article

\title{
Developing an Ecosystem Services Online Decision Support Tool to Assess the Impacts of Climate Change and Urban Growth in the Santa Cruz Watershed; Where We Live, Work, and Play
}

\section{Laura Norman ${ }^{1}{ }^{*}$, Nita Tallent-Halsell ${ }^{2}$, William Labiosa ${ }^{1}$, Matt Weber ${ }^{3}$, Amy McCoy ${ }^{4}$, Katie Hirschboeck $^{5}$, James Callegary ${ }^{1}$, Charles van Riper III ${ }^{1}$ and Floyd Gray ${ }^{1}$}

1 U.S. Geological Survey, Western Geographic Science Center, 520 N. Park Avenue, Suite \#102K, Tucson, AZ 85719-5035, USA; E-Mails: blabiosa@usgs.gov (W.L.); jcallega@usgs.gov (J.C.); charles_van_riper@usgs.gov (C.R.); fgray@usgs.gov (F.G.)

2 Environmental Sciences Division, Landscape Ecology Branch, U.S. Environmental Protection Agency, 944 East Harmon Ave., Las Vegas, NV 89119, USA;

E-Mail: Tallent-Halsell.Nita@epamail.epa.gov

3 Sustainabile Technology Division, U.S. Environmental Protection Agency, 200 SW 35th Street, Corvallis, OR 97333, USA; E-Mail: Weber.Matthew@epamail.epa.gov

4 Office of Arid Lands Studies, The University of Arizona, 1955 East Sixth St., Tucson, AZ 85741, USA; E-Mail: amccoy@email.arizona.edu

5 Laboratory of Tree-Ring Research, The University of Arizona, 208/West Stadium, Tucson, AZ 85719, USA; E-Mail: katie@1trr.arizona.edu

* Author to whom correspondence should be addressed; E-Mail: lnorman@usgs.gov; Tel.: +1-520-670-5510; Fax: +1-520-670-5113.

Received: 2 June 2010; in revised form: 25 June 2010 / Accepted: 29 June 2010 /

Published: 9 July 2010

\begin{abstract}
Using respective strengths of the biological, physical, and social sciences, we are developing an online decision support tool, the Santa Cruz Watershed Ecosystem Portfolio Model (SCWEPM), to help promote the use of information relevant to water allocation and land management in a binational watershed along the U.S.-Mexico border. The SCWEPM will include an ES valuation system within a suite of linked regional driver-response models and will use a multicriteria scenario-evaluation framework that builds on GIS analysis and spatially-explicit models that characterize important ecological, economic, and societal endpoints and consequences that are sensitive to climate patterns, regional water budgets, and regional LULC change in the SCW.
\end{abstract}


Keywords: arid lands; climate change; decision support tool; drought; drylands; ecosystem portfolio model; ecosystem services; environmental justice; socio-ecologic vulnerability

\section{Introduction}

The limited availability of water, rapidly increasing population, and diminishing quality of life are negatively impacting ecosystem services and human well-being in the arid and semi-arid borderlands of the United States and Mexico (Figure 1) [1,2]. The primary challenge for decision makers is to decide on the optimal allocation and sustainable management of water and land yet there are few tools currently available to assess the tradeoffs [3]. The Santa Cruz Watershed Ecosystem Portfolio Model prototype (SCWEPM), an integrated water and land management and decision-making tool was started in June 2009 (see Box 1) with the intent to deliver predictive modeling and decision-support capability that can be used to forecast responses to policy and management decisions on natural resources based on changes in water availability, land use/land cover (LULC) and climate scenarios. The SCWEPM uses a multicriteria evaluation framework that builds on geographic information system-based (GIS) analysis and spatially explicit models that characterize ecological, economic, and societal endpoints and consequences, as identified by stakeholders, that are sensitive to modifications to water and land management.

Figure 1. Location map of the US-Mexico borderlands with the Santa Cruz watershed borders in bold and diagonally hatched [7].

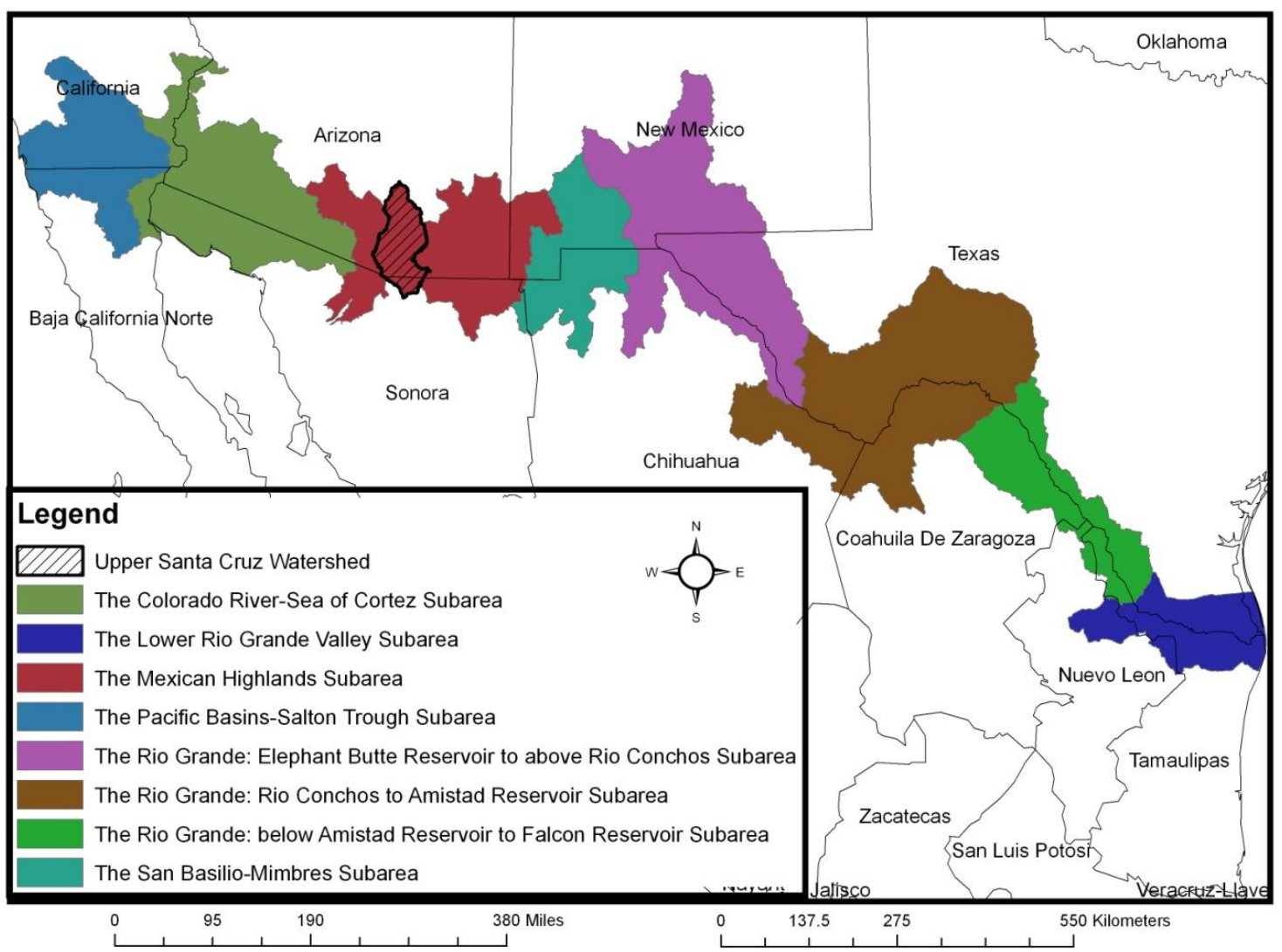


Box 1. In a meeting held in June, 2009, an interdisciplinary, multi-agency team developed a research question from which to focus our integrated intentions:

Question: What are the ecosystem services (ES) that contribute to physical, biological, and social qualities and resilience of the Santa Cruz Watershed and how can these be interlinked to support decision-making and management objectives,

-to create a support tool for management of urban development and respond to climate change,

-to assess and value the ES of the watershed and landscape,

-to visualize impacts of a range of scenarios on people's quality of life,

-to operationalize the decision-making process,

-to define transparent indicators of intangible issues, like sustainability and

environmental justices,

-that recognizes the complexity and unpredictability of the systems, and

-that considers tradeoffs relating to competing perspectives of stakeholders?

Ultimately the SCWEPM will map changes in ecosystem services resulting from alternative water availability and land use scenarios. Since the 1960s the concept of ecosystem services (ES; i.e., the goods and benefits people obtain from ecosystems for which people can express preferences that allow tradeoffs to be evaluated [4,5]) has been gaining momentum as a framework to integrate ecological function and economics in a manner useful for evaluating tradeoffs in natural resource management [1-6]. The goal of using ES is to balance competing interests when deciding how best to manage and allocate natural resources $[4,6]$. The SCWEPM will enable the consideration of which and in what ways ecosystem services will be impacted based on a suite of water availability and land use scenarios.

The intent of this paper is to describe the SCWEPM. In the following sections we will (1) give a brief description of the study area, (2) describe the SCWEPM; (3) identify the ES, alternative future scenarios, and linkages with human well-being that will be considered in the first phase of the prototype; (4) describe our approach and (5) summarize the challenges and opportunities for improving the science and practical applications of the SCWEPM.

\section{Study Area}

The Santa Cruz watershed (SCW), located in Southern Arizona and Northern Sonora (Figure 2), is approximately 910,300 ha $(2,249,390$ acres $)$ and ranges in elevation from 668 to 2,846 m $(2,192$ to $9,337 \mathrm{feet}(\mathrm{ft}$ ); average $1,240 \mathrm{~m}$ or 4,068 ft). The Santa Cruz River is an ephemeral tributary that drains into the Gila River, which is a branch of the Colorado River [8]. The headwaters of the Santa Cruz River are located in the San Rafael Valley of southeastern Arizona. The river flows southward into Sonora, Mexico, turns westward and reenters the United States just to the east of Nogales, Arizona. It then continues northward to converge with the Gila River. The administration and ownership of the SCW is divided into four governing Nations: the Tohono O'odham Nation, Pascua Yaqui Tribe, Mexico, and United States. 
Figure 2. Map of the Santa Cruz watershed.

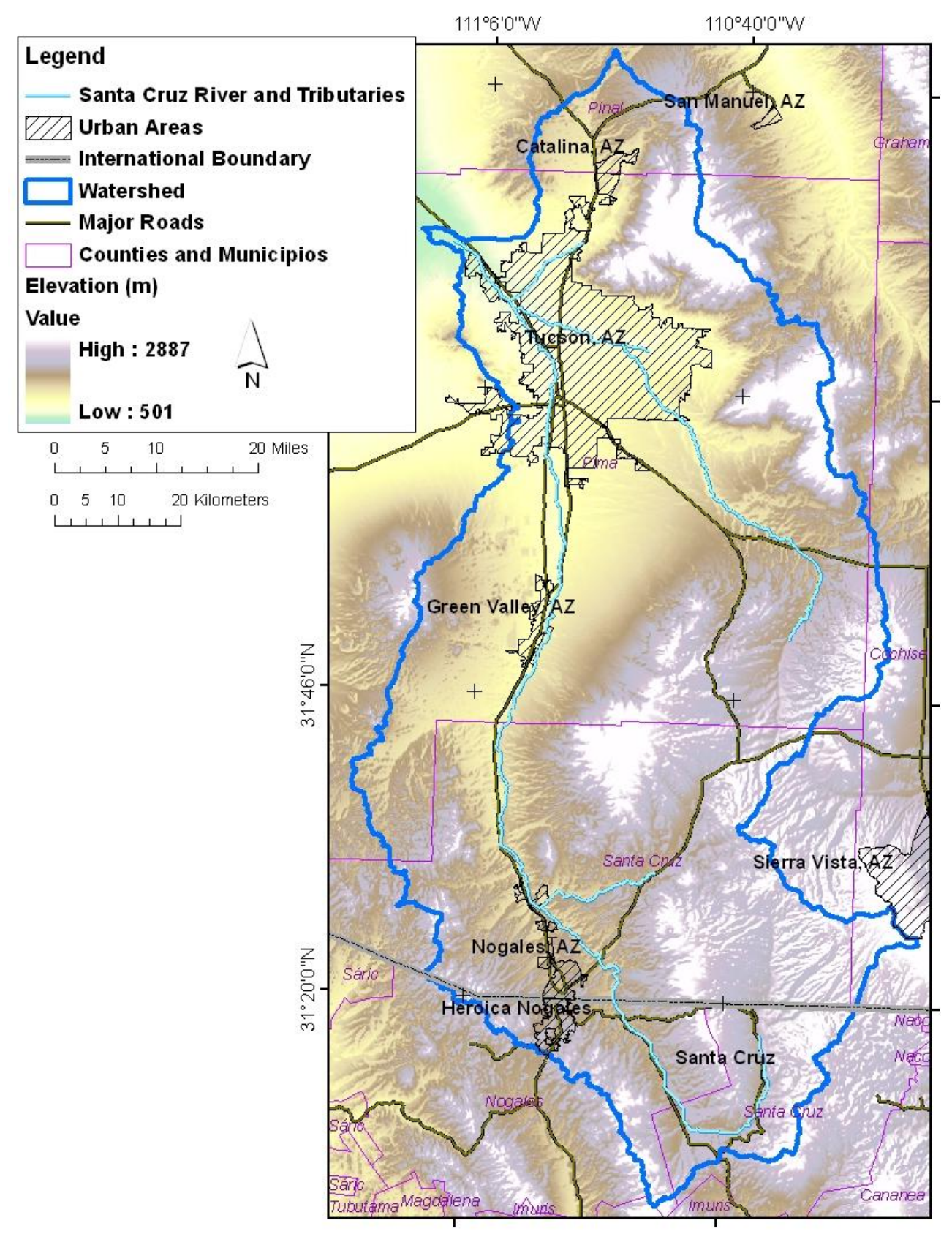

The SCW is a microcosm of border complexity; large populations in international communities fuse farming, ranching, mining, industry, and trade, whilst sharing common surface and ground waters [8-10]. Urban expansion, intensified agriculture and resource extraction, and over allocated water resources development has impacted the people, economy, and natural resources significantly [9-14]. As a result, the SCW is at high risk of losing essential ES [15].

\section{Santa Cruz Watershed Ecosystem Portfolio Model (SCWEPM)}

Developed previously for land use planning in South Florida, the Ecosystem Portfolio Model (EPM) framework is a map-based multicriteria evaluation tool that stakeholders can use to explore tradeoffs between valued ES at multiple scales for use within a participatory decision process [16]. It is 
integrated into a regional water management and land-use planning Web tool that models changes in ES under various scenarios for important drivers including climate change, land cover change, demographic changes, and regional economic changes [16]. For terrestrial ecosystems, land-cover change is one of the most important direct drivers of changes in ES [17]. More specifically, the fragmentation of habitat from expanding low-density development across landscapes appears to be a major driver of terrestrial species decline and the impairment of terrestrial ecosystem integrity, in some cases causing irreversible impairment from a land-use planning perspective [18-20]. The EPM is an attempt to integrate important aspects of the coupled natural-system/human-system view from a regional planning perspective.

There are several other GIS- and Web-based land-use planning tools (e.g., CITYgreen [21], Smart Places [22]), ecosystem management tools (e.g., Ecosystem-Based Management Tools Network [23]) and regional ecosystem services assessment and valuation tools (e.g., Natural Capital Project Integrated Valuation of Ecosystem Services and Tradeoffs (InVEST) [24]; ARIES [25]; Multiscale Integrated Models of Ecosystem Services (MIMES) [26]). However, these tools have a different focus, methodology, and/or intended use. They are designed to be general tools that must be customized with local data and expert knowledge in a specific place and context.

In contrast, the EPM is designed to be used as a place-specific set of Web-accessed tools implemented for a holistic ecosystem analysis. Also, the EPM is designed to enable an unbiased view of the regional impacts and tradeoffs inherent in land-use changes. From this perspective, ecological, economic, and societal or "quality-of-life" endpoints get represented separately, allowing decision-makers to consider ecological-economic-community value tradeoffs explicitly rather than combining these categorically-distinct values. Based on direct input from stakeholders and potential end-users (i.e., on-going meetings and interviews) the EPM focuses on three dimensions of land-use/land-cover (LULC) related anthropocentric value (i) ecological-value (based on various ecological criteria), (ii) market land-price, and (ii) indicators of (human) community quality-of-life or human well-being [16]. Each of these dimensions is implemented as a submodel of the EPM that generates "value maps" for a given land-use pattern, where the value map reflects changes in land attributes and patterns, as well as user preferences (the exception is the land-price model, which reflects market prices outside of the influence of the individual user) [16].

These attributes are primarily related to LULC, including changes in habitat potential and landscape fragmentation, human perceived amenities, community character, flooding risks, water-quality buffer potential, and ecological restoration potential. Note that a model result considered "desirable" (e.g., increased habitat potential as derived in the ecological-value model) may be considered "undesirable" based on another criteria (e.g., increased travel time to retail establishments as derived in the community quality-of-life model), generating conflicting scores for a given land-use pattern. The advantage of the EPM is that it is designed to allow users to consider trade-offs between competing values and also to consider synergies or bundles (positive relationships among ES). The value maps can be disaggregated into underlying individual criteria values, as well as viewed as aggregated value maps.

The EPM is designed to be used by various users specific to their missions and mandates, such as: (a) Federal, State, tribal and local natural resource agency staff and managers that have land use and development responsibilities; (b) stakeholders evaluating development applications, land-use plans and 
trends; (c) local and regional planning agencies considering the potential ecological impacts to protected public lands and undeveloped private lands; and (d) resource agencies communicating with land-use decision-makers and other stakeholders about the potential effects of land-use change. The EPM Web interface allows users to select from a list of existing land-use plans or upload their own land-use plans using a specified classification system, and, through the Web interface, to interactively modify the land-use classifications of any cells or parcels within a loaded land-use plan.

The EPM for the SCW will include an ES valuation system within a suite of linked regional driver-response models. The SCWEPM will use a multicriteria scenario-evaluation framework that builds on GIS analysis and spatially-explicit models that characterize important ecological, economic, and societal endpoints and consequences that are sensitive to climate patterns, regional water budgets, and regional LULC change in the SCW (Figure 3).

A multi-attribute utility preferences framework represents a methodological middle ground between detailed economic analysis, that make many strong assumptions about the domain of application[27], and public participatory methods that reflect the preferences of a single group of individuals, which can be non-representative of the broader collection of stakeholders [28]. The use of standard economic tools based on marginal analytic techniques applied to ES is limited to situations in which relatively intact ecosystems are functioning within stationary patterns that are far away from sudden irreversible changes [27]. Our approach is to combine these approaches and engage stakeholders to define a collection of focal ES attributes.

The SCWEPM will use methods from decision sciences and economics to quantify public values over time. There are many types of participants engaged in water management decision-making in the SCW; local, regional, State, and Federal agencies, tribes and tribal agencies, environmental groups, agricultural groups, and other stakeholders. The SCWEPM's multicriteria evaluation framework is designed to cut across the objectives and knowledge bases of all of these participants. Environmental and ecological models estimate criteria scores, that are weighted using user-defined weights (to reflect preferences) and combined with other criteria. This approach places fundamental importance on social equity and stakeholder participation, but makes no attempt to determine normative socially "optimal" land-use plans. The SCWEPM is thus a map-based set of evaluation tools for planners and stakeholders to use in their deliberations of what is "most desirable", considering a balancing of disparate interests within a regional perspective.

The SCWEPM is intended to provide transparent first-order indications of the direction of ecological, economic, and community change, not to make detailed predictions of ecological, economic, and social outcomes. In short, the SCWEPM will widen the perspectives of its users by integrating natural and social scientific information in a framework that recognizes the diversity of values at stake in water management and land-use decision-making. In this project we propose to address many research and management questions using the proposed decision support tool under a suite of climate and population change and impact scenarios. In the subsequent section we provide a detailed synopsis and overview of ES in the study area, proposed scenarios, and ecological and societal endpoints to be addressed. While each of the sub-models being applied can generate quantitative results, the scale and combination increase associated error, and so, it is worthy to note that the models being applied within the EPM will be used to evaluate relative change and can only provide qualitative 
estimates. Reliable quantitative estimates would require more intensive calibration and high-resolution data. It is also subject to the assumptions and limitations of its component models.

Figure 3. Schematic of SCWEPM model inputs, outputs, and sub-model interactions.

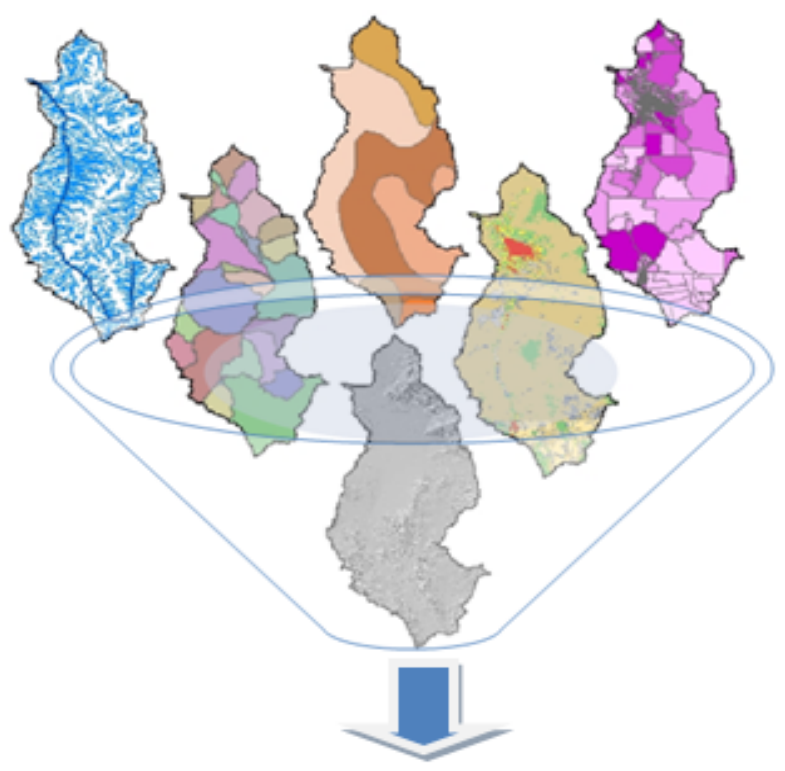

Data Input to Environmental Models

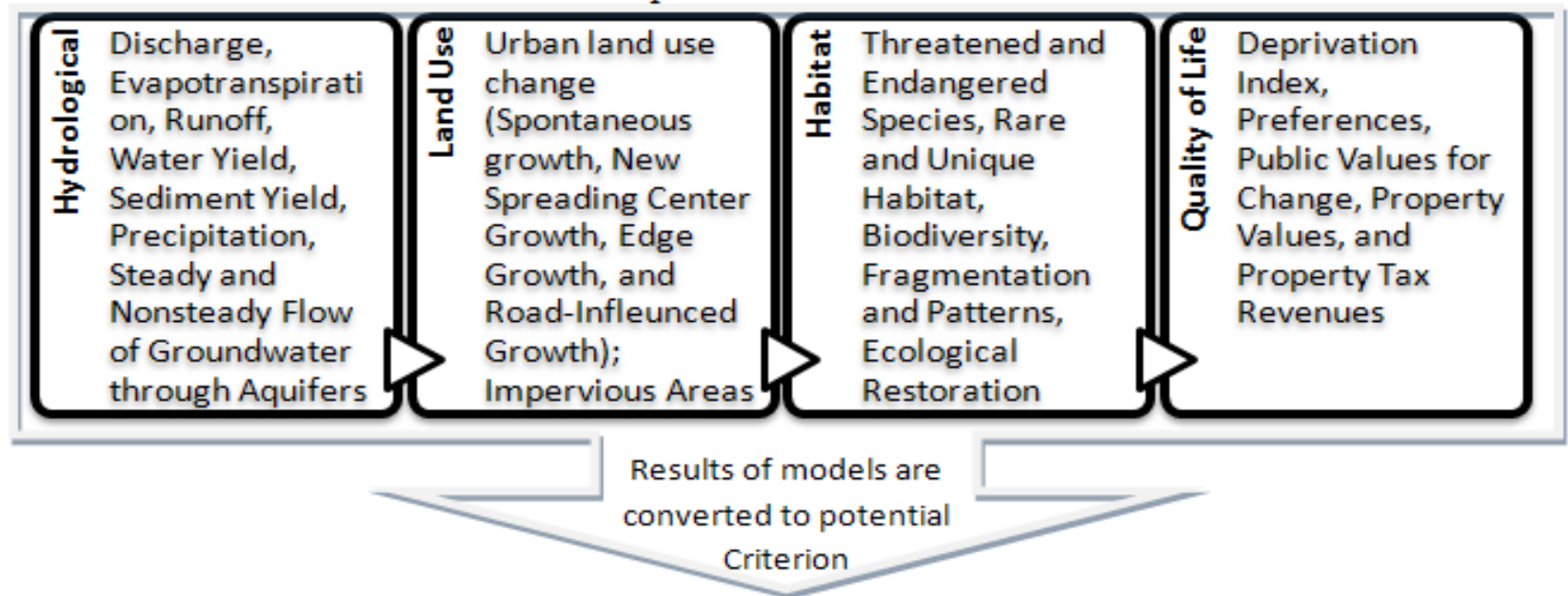

User-elicited value judgments and criteria scores are combined to generate Ecosystem Service Value Maps

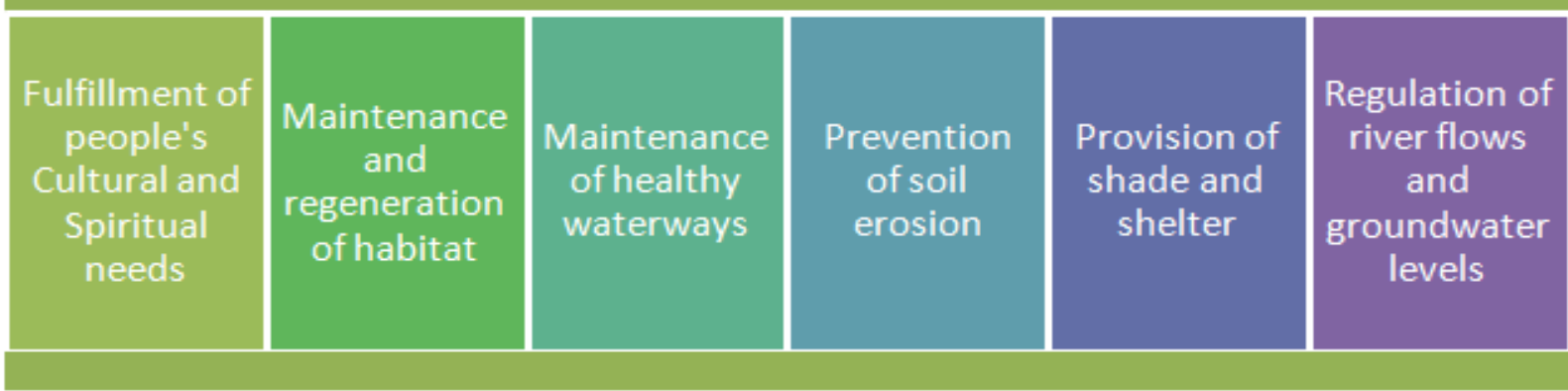




\section{Ecosystem Services, Alternative Future Scenarios, and Human Well-Being}

\subsection{Ecosystem Services}

Ecosystem services science is evolving. Since the release of the Millennium Ecosystem Assessment [29] a substantial research effort has been deployed to understand and quantify how ecosystems provide services, how to value ES, the use of ES in trade-off analysis and decision making, and the use of ecosystem services in planning and management [3]. Society is dependent on the long-term functions of ecosystems and their productive capacity for the supply of food and raw materials. In turn, resources and services obtained from nature should be used efficiently within the society. Social efficiency means that resources must be used where they are needed most, which leads to the requirement of just distribution of resources among human societies and human beings [30]. The usual goal in managing ES is to focus on aggregate levels of benefits, and distributional issues are lost or deferred. We will be addressing both the questions related to ES services and the just distribution of ES as we develop the SCWEPM. The services that we will focus on are water and habitat provisioning. The project will expand its scope in terms of ES as things move forward.

\subsubsection{Water provisioning}

The Santa Cruz watershed is characterized by high temperatures (average annual temperature is $66^{\circ}$ Fahrenheit $\left(\sim 19^{\circ}\right.$ Celsius) [31] and limited rainfall (average annual precipitation is 14 inches ( 0.36 meters) [31]. Shallow aquifer formations are fed primarily by mountain-front recharge from seasonal rain and snow. Groundwater quality is affected by the heavily mineralized and hydrothermally altered rocks found in the adjoining mountains. In the portion of the Santa Cruz River near Nogales, most water is derived from the floodplain aquifer, a series of shallow and undulating micro-basins that are composed principally of unconsolidated sands and gravels which together are called the Younger Alluvium [32]. These aquifers have high permeability and storage capacity and therefore contain most of the locally accessible water in the Nogales area [33].

The health of the SCW riparian ecosystem is dependent on periodic flooding, followed by periods of drought. Large flooding events redistribute nutrients and sediments and scour native trees (Family Salicaceae), exposing sand bars and riverbanks that are suitable for establishing native and invasive plant taxa. Implications of invasive species outside the riparian corridor, specifically upland range grasses (considering fire, hydrologic regimes, etc.) are unknown. Annual precipitation patterns drive the growth cycle of riparian trees. Trees rely on shallow water tables and stored reserves from winter rains to endure the hot and dry months from April until July, when the monsoon rains begin. Monsoon floods are critical to maintaining a healthy riparian system (recharge aquifers, disperse seeds, induce seed germination and clear debris from forest floor) [34]. During periods of drought, the width of the stream may decrease as riparian vegetation increased in the channel. Drought and floods resulting from changes in climate alter the composition, structure, and function of riparian areas $[35,36]$.

There is insufficient surface- and ground-water to meet all of the needs of the growing human communities and ecological systems [13] on the Arizona-Sonora border placing a growing demand for novel ways to augment water supplies. Groundwater is pumped from major well fields along the Santa Cruz River, south of Nogales, Sonora in the Los Alisos Basin, and from well fields north and east of 
Nogales, Arizona. North of the confluence of Nogales Wash and the SCR, the horizontal extent of both the Younger and Older Alluvium increases relative to the microbasins area [37]. Further north, in the Tucson basin groundwater is augmented by Colorado River water through the Central Arizona Project canal system (CAP). CAP waters are being imported into the SCW the maximum allocation at a rate of over 140,000 acre-feet (ac-ft) per year [38]. If population growth continues as projected [39], additional water may be required from outside the SCW. The Alisos Basin, south of Nogales, Sonora is currently being constructed [40]. In the event that climate change (e.g., reduction in precipitation, increase in air temperature) diminishes returns to water augmentation, many ES will need to be sustained by active water management; there is growing interest and appreciation for the roles of effluent and of rainwater harvesting as underutilized water resources.

Energy is needed to support water services (e.g., agricultural pumping, irrigation, and wastewater treatment) in the SCW on both sides of the border, increasing the complexity of integrated water management. Transferring waters in Sonora via the Los Alisos (Rio Magdalena-Nogales) aqueduct entails significant energy [40] for pumping. The energy required to import CAP water will be even greater. Incorporating water imports into the modelling platform will enable the comparison of energy use and economic and ecological costs associated with importing water, and thus allowing decision makers to discern the impacts on regional aquifers, agriculture, habitat biodiversity, flow regimes, and human quality of life.

While surface flow in the river is now ephemeral and intermittent from the headwaters, through Sonora, and back into Arizona, a perennial reach of the river runs for about 30 miles as a result of daily effluent discharges from the Nogales International Wastewater Treatment Plant (NIWWTP). The NIWWTP began operation in the 1970's and reached its current discharge rate in mid-1990. Due to intensive groundwater pumping to support agricultural operations and growing municipalities the once abundant and dense riparian forest along the river had been diminished by the 1970s. Daily inflows of effluent from the NIWWTP now supply the riparian ecosystem (Figure 4) that many vertebrates and invertebrates are dependent upon for either temporary or permanent habitat. A similar effluent-dependent reach exists where the two main wastewater recharge plants in Tucson discharge into the river.

Studies have been conducted on the role of effluent in the system and have shown that effluent plays a significant role in supporting riparian and aquatic ecosystems [41-44]. However, uncertainties remain, as it compromises ecological integrity due to poor water quality and emerging contaminants [45]. Downstream of the treatment plants, augmentation of recharge and water to support riparian vegetation rely on annual monsoon floods. These floods also remove the clogging algae layer that develops as the result of high nutrient concentrations in effluent. In prolonged or intense drought the clogging layer will persist thereby reducing infiltration and causing die-off of riparian vegetation [46]. However, there has been little research comparing the health of natural systems to the health of effluent-dominated systems. The primary perennial surface water source in the SCW is treated effluent. Although atypical, the ES derived from wastewater provide waters and nutrients for riparian and aquatic flora and fauna. 
Figure 4. Photograph of the Santa Cruz River, Arizona, USA, approximately 9 miles downstream of the Nogales International Wastewater Treatment Plant (photo courtesy of Hans Huth; 28 October 2008).

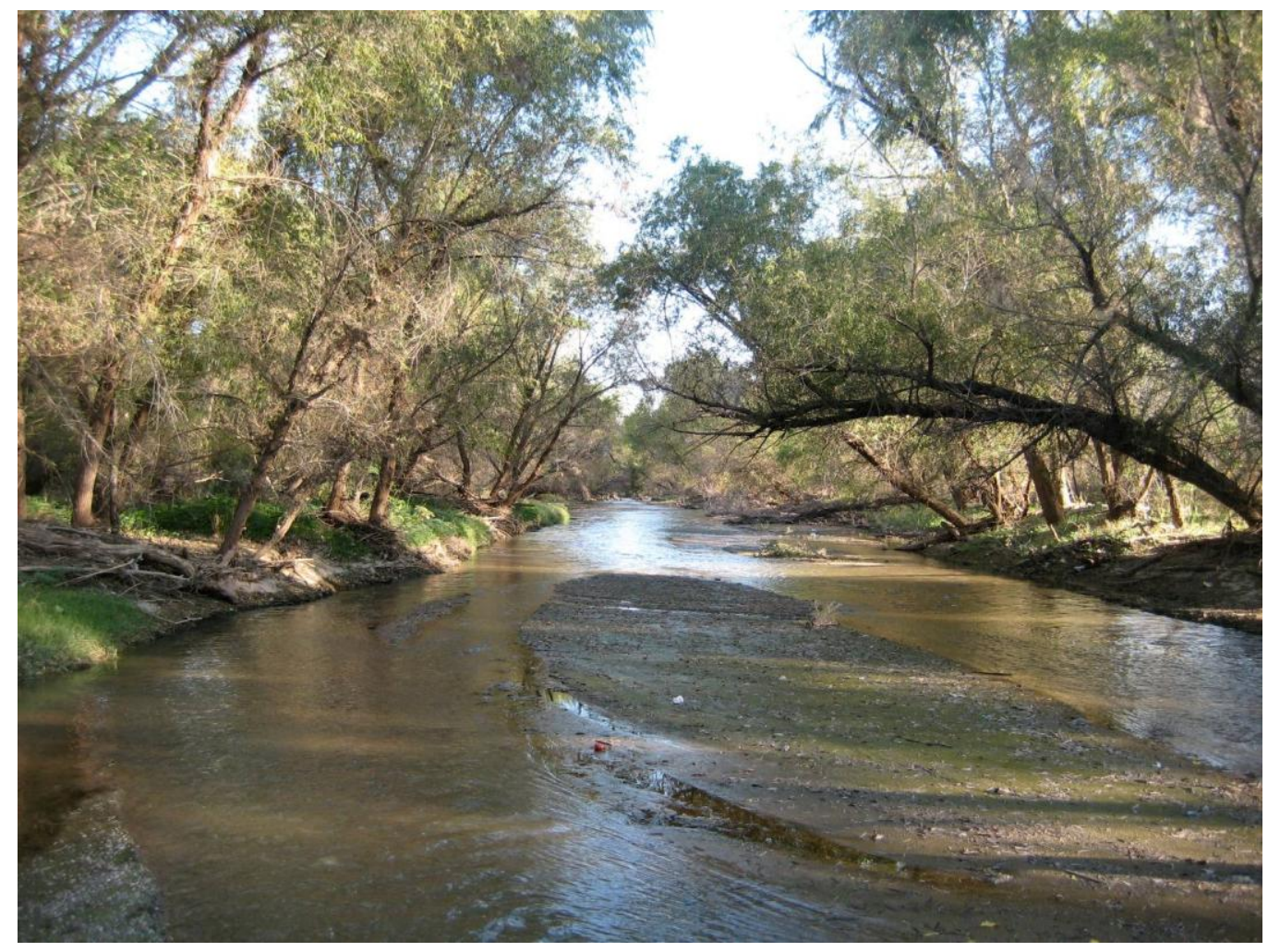

Effluent is managed locally and internationally. Portions of the effluent are reclaimed for off-channel landscape irrigation purposes. Tucson has a delivery system for reclaimed water and has subsidized extending this for clients, but currently most of the effluent is discharged into the channel. There is substantial pressure for this to change. As part of its Water Plan, the City of Tucson plans to treat effluent to potable standards and include it in the general delivery system to meet projected demand. Other regions in the Southwest, such as Orange County CA, and El Paso Texas, already utilize a far higher proportion of available effluent for off-channel and indirect potable use purposes.

Internationally, the NIWWTP treats inflows from both Mexico and the US. Mexico does not have the capital for large-scale wastewater treatment in Nogales, but with international funding there are concept plans for delivery to a plant in Los Alisos, Mexico that would reclaim the water for agricultural purposes. The main driver for the plant is limited capacity at the NIWWTP, but it signals the beginning of what may be a shift of water resources to off-channel uses in Mexico. In the current international agreement, Mexico is billed proportionally for inflows up to $9.9 \mathrm{mgd}$, and then billed extra for flows beyond. However the treated water is not returned to Mexico. It is conceivable that through renegotiation with the International Boundary and Water Commission that manages the NIWWTP, Mexico could eventually reclaim its entire share of the inflow.

As future pressures of climate and population change increase, it is important to proactively consider the different ES associated with managing effluent. With each management option, there are costs as well as ecosystem service benefits, with net benefits depending on many factors. Two competing uses of effluent can be distinguished as in-channel and off-channel. In-channel benefits 
include the existence of riparian vegetation and wildlife, enhanced recreational potential, enhanced property value potential, aquifer storage, and groundwater supply. In-channel costs include odor problems, potential human contact health hazards, and ecological impacts. Off-channel benefits include delivery for potable and non-potable purposes; while costs include delivery infrastructure.

These ES may have market prices to indicate their value, or may be nonmarket in nature. There may also be externalities that bear on the issue. For example, residential water rates usually only include the cost of treatment and delivery, but not the value of the water itself; an externality caused by underpriced water is fewer water supplies for the future. The SCWEPM will provide a means to consider the relative costs and benefits of managing effluent.

Rainwater harvesting is a traditional water collection technique that involves either active storage of collected water in a receptacle (e.g., tank), or regrading surface topography to slow or capture runoff to increase water storage in sediments. Although rainwater harvesting is less practiced at present, presumably due to the convenience of modern water delivery infrastructure, retaining water onsite can obviate the need for landscape irrigation, enhance groundwater recharge, and mitigate downstream impacts. There is renewed interest in the net ecosystem benefits of traditional rainwater harvesting being considered. For example, the City of Tucson requires commercial building constructed after June 10, 2010 to augment at least $50 \%$ of their landscaping needs with harvested rainwater water [47].

Both rooftop or small-scale urban systems, and landscape-scale runoff capture systems will be modeled. Potential ecosystem service benefits of increased rainwater harvesting are similar to those listed above for effluent. Costs stem from project installation and maintenance. A complicating issue is that rainwater harvesting efforts at the watershed scale are most effective when small, dispersed projects are enacted high in the watershed and are continued to the mouth. These often occur on private lands and hence the ability for regional agencies to rely on these projects is uncertain. This leads to central, engineered solutions such as large detention basins low in a watershed, rather than greener solutions throughout [48].

\subsubsection{Habitat provisioning}

The SCW is rich in riparian areas, unique desert habitats, diverse canyons, and extensive Sky Island landscapes, providing habitat for wildlife and cultural services and amenities such as aesthetically-pleasing landscape, recreation, cultural heritage, and spiritual and religious inspiration. The riparian corridor of the Santa Cruz River and its tributaries provide an important migratory corridor for millions of Neotropical migrants and large numbers of wintering and migrating waterfowl that regulate insects that feed on fields and native plants [49] (Table 1). Several upland, riparian and aquatic avian species are hunted recreationally (e.g., turkey [Meleagris gallapavo merriami and mexicana], scaled quail [Callipepla squamata], mearn's quail [Cytonyx montezuma], band-tailed pigeon [Patagioenas fasciata] and mourning dove [Zenaida macroura]).

The SCW is also home to diverse reptiles and amphibians taxa due to the heterogeneous landscape. Nine of 17 species of rattlesnake (genera Crotalus and Sisturus) that occur in Arizona are found in the SCW. Half of the 26 native species of amphibians found in Arizona occur there (all of which are of conservation concern), including three of Arizona's seven species of native frogs. This area is an important hot-spot for native amphibian and reptile diversity preservation and conservation. 
Table 1. Birds found in the Santa Cruz watershed.

\begin{tabular}{|c|c|}
\hline Birds & \\
\hline Summer Tanager & Piranga rubra \\
Yellow Warbler & Dendroica petechia \\
Yellow-breasted Chat & Icteria virens \\
Gray Hawks & Asturina nitida \\
Yellow-billed Cuckoo & Coccyzus americanus \\
Lucy's Warbler & Vermivora luciae \\
Bell's Vireo & Vireo bellii \\
Abert's Towhee Northern & Pipilo aberti \\
Beardless-Tyrannulet & Camptostoma imberbe \\
Varied Bunting & Passerina versicolor \\
Rufous-winged Sparrow & Aimophila carpalis \\
Lazuli Buntings & Passerina cyanea \\
Indigo Buntings & Passerina amoena \\
Tropical Kingbird. & Tyrannus melancholicus \\
\hline
\end{tabular}

Fish surveys conducted by the Arizona Game and Fish (AZGF) in the SCR at the SCR, North of Rio Rico and the Santa Cruz, at Rio Rico from 1998 to 2003 revealed the presence of mosquito fish (Gambusia affinis), longfin dace (Agosia chryogaster) gila topminnow (Poeciliopsis occidentalis), and desert suckers (Catostomus clarki). Surveys in 2007 and 2008 reveal that fish are absent from just below the treatment plant and depauperate at more northern sites. A study of the bioaccumulation of trace elements and pesticides in multiple species and at different trophic levels conducted by the U.S. Fish and Wildlife Service (FWS) in 1997 [50]. The study indicated that wastewater discharged from the NIWTP has limited populations of aquatic macroinvertebrates and fish species (i.e., two fish species of fish, desert sucker [Catostomus clarki] and longfin dace [Agosia chrysogaster]; three aquatic macroinvertebrate species; giant water bugs (Belostoma sp.), dragonfly larvae (Aeshnidae) and aquatic snails (Physa viragata); and one avian species, killdeer (Charadrius vociferous) were collected).

The potential distribution of mammals, fish, birds, amphibians, and reptiles can be mapped based on known ranges and habitat preference. Watershed species diversity and incidence of threatened and endangered can be gleaned from these maps. Recreational hunting is also popular in the SCW. Maps of the distribution of game species are included in the SCWEPM to enhance refuge and wildlife management's ability to consider the impact of climate change on management and conservation practices.

\subsubsection{Cultural resources provisioning}

The SCW is rich cultural resources that are unique to the United States and Mexico (e.g., remains of prehistoric and historic Indian villages, Spanish colonial missions and a presidio, and early Anglo and Mexican ranches, ruins of Spanish period missions and a presidio; the Tohono O'odham Nation's late 18th-century church at the San Xavier District). The watersheds natural resources and open spaces have aesthetic and recreational values, including numerous rural roads, trails, camping facilities and 
fishing opportunities. SCW residents and visitors enjoy unobstructed views of scenic landscapes, as well as clear night skies and the absence of lights in the desert for star gazing.

\subsection{Alternative Scenarios}

Scenario analysis is a strategic planning technique used to describe and evaluate a plausible description of what might happen. They are not forecasted, but rather carefully constructed plots based on probable drivers of future states and conditions. They are used to assist in decision-making, making stakeholders aware of the ramifications and uncertainties of their actions.

\subsubsection{Urban growth scenarios}

Urban growth is a primary driver of land use change in rural and metropolitan areas in the SCW. According to the 2000 U.S. Census, Arizona was the nation's second fastest growing state from 1990 to 2000. Tucson is the largest urban area in the watershed, with over a million people living in the metropolitan area, half of which live within the Tucson city limits. Nogales, Sonora is second largest with over 300,000 people.

Urban and non-urban land-use (i.e., population growth and shifts) will be modeled using the SLEUTH Urban Growth Model, that simulates transition of land-use using cellular automata and generates dynamic spatial patterns by applying growth rules to a grid of cells [51,52]. Each land-use state is modeled from local factors (e.g., roads, existing urban areas, topography), as well as temporal and random factors. Additionally, non-urban land use transitions, such as rangeland to agricultural land, will be simulated. The output maps of annual forecasted change can be animated to show change over time as well as integrated into GIS databases to allow for further spatial analyses.

The outputs of the SLEUTH simulations will be fed back into the SCWEPM to determine predicted impervious surfaces impacts on water quantity and habitats downstream. Additionally, the SLEUTH output will be used to assess demographic responses to climate impact scenarios, including forced migration, and overcrowding, and to demonstrate the impact population movement might have on cultural resources.

\subsubsection{Climate change scenarios}

The SCW climate is characterized as arid to semi-arid, with heavy summer monsoon rains accounting for the majority of precipitation and winter cyclonic events accounting for a smaller amount [53]. Evapotranspiration demands are highest in June, prior to the start of the summer "monsoon" rainy season. The watershed is located in a transition zone between temperate and tropical latitudes and between regions with summer-dominated rainfall to the east and south and winter-precipitation dominance to the west and north. Superimposed on this is a vertical climatic transition due to elevation changes, with cooler temperatures and greater precipitation at higher elevations. This positioning with respect to climate transitions governs the watershed's bimodal rainfall, leads to fluctuating streamflow regimes, enhances the basin's sensitivity to climatic variations, and exacerbates the watershed's vulnerability to climatic change. 
Processes which deliver moisture to the region vary seasonally. Winter precipitation is dependent on the southern reaches of large, synoptic-scale cyclonic storms arising in the North Pacific Ocean, while during the summer rainy season (late June through September), convective thunderstorms dominate. Periodically, additional moisture is entrained into the region during the warm season from remnants of eastern North Pacific tropical storms [54,55]. The atmospheric dynamics associated with these mechanisms lead to an important distinction regarding the seasonal nature of precipitation. Due to variations in large-scale synoptic circulation patterns that dictate the trajectories of extratropical cyclonic storm tracks, precipitation exhibits greater interannual variability at a given station during winter than summer, even though summer convective rainfall is more spatially variable [56]. Nevertheless, summer and fall station rainfall totals can fluctuate widely during years affected by tropical cyclone-related moisture influxes.

A watershed-centered approach of process-sensitive upscaling built upon the basin's streamflow hydrology and using the river's response to known weather and climate processes, will be the basis for future climate change scenarios compared in the SCW [57]. The interaction between storm properties and drainage basin properties (e.g., area, slope, elevation) plays an important role in the occurrence and magnitude of floods and droughts both regionally and seasonally. A watershed's streamflow may be a better indicator of overall climate variability than gauged precipitation because it assimilates weather input over space and time and is dictated by basin-wide runoff processes that are dependent on temperature and evapotranspiration as well as precipitation. Discharge variability therefore reflects a suite of integrated hydroclimatic processes that might be difficult to detect in other measurements of the climate system. Discharge is the phenomenon most directly associated with water supply, water quality, riparian ecosystem health, and hence an understanding of how climate change and streamflow interrelate through process-sensitive upscaling can provide an important foundation for an integrated assessment of watershed-based ES.

Variations in the magnitudes, frequencies, and seasonal characteristics of the streamflow events can be reevaluated in terms of the meteorological causes and large-scale circulation patterns [58]. Analyses have demonstrated that the time series of peak flow events at stations throughout the SCW reflect a combination of floods caused by seasonal differences in precipitation as previously noted, i.e., winter synoptic storm floods, summer convective storm floods, and floods associated with moisture from remnants of tropical cyclones [58,59]. Summer convective storms are the most frequent source of flooding, but six of the seven largest annual floods at the Tucson gage (all of which occurred in the second half of the record) were associated with either tropical or extratropical cyclones (Figure 5).

For example, GCM projections of a poleward shift in the position of the westerly extratropical storm track indicate a scenario with a diminished influence of the winter synoptic flood type in the SCW, whereas model projections of a more active tropical storm regime specify a scenario of enhanced tropical-storm related flooding. Clearly, any shift toward a stronger or weaker summer monsoon thunderstorm season in Arizona would have a profound influence on the dominant source of flooding, recharge, and overall flow regime in the watershed. Moreover, timing of floods and flow greatly affects ecosystem dynamics [34]. 
Figure 5. Annual flood peak discharge in thousands of cubic feet per second for the SCR classified according to hydroclimatic cause of flood. Period of record is 1915-1999. Data are for the Santa Cruz at Tucson (USGS gage No. 09482500).

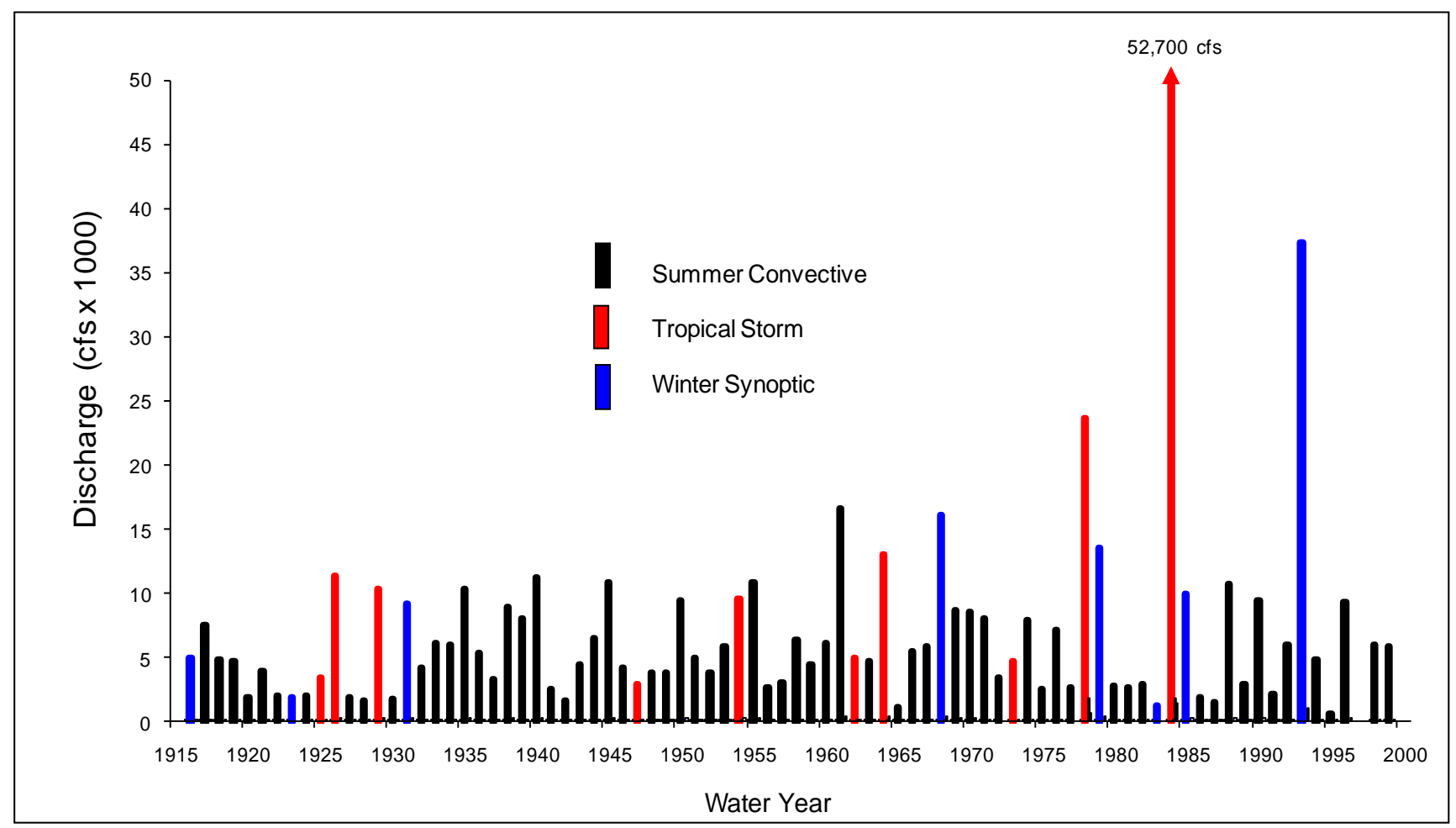

Our upscaling approach will use high resolution climate modeling information and derivative products to produce impact-relevant information needed to forecast ecological and population response at regional levels. Using that, we will assess the vulnerability and risk of species and habitats to climate change. An assessment of climate change impacts in the water resources of the San Pedro River basin, just east of the SCR, was done by Sustainability of Semi-Arid Regions and Riparian Hydrology (SAHRA), who presented results from 17 global circulation models (GCMs) and four different climate change scenarios from the Intergovernmental Panel on Climate Change (IPCC) [60]. Drawing from these results, we will downscale precipitation data to use as input of representative climate scenarios into the basin's existing decision support system model.

Climate scenarios 30-50+ years in the future that are generated by the IPCC and the North American Regional Climate Change Assessment Program (NARCCAP) will be the bases for analysis, impacts studies, and further downscaling. These scenarios will be interpolated into Parameter-elevation Regressions on Independent Slopes Model (PRISM) geospatial climate mapping system of the watershed to generate and visualize GIS-scenarios of watershed predictions from regional climate models (RCMs) that are driven by a set of atmosphere-ocean general circulation models (AOGCMs) and downscaled using high-resolution digital elevation models and local stream gage information. These forecasts will be criterion available for scenario building and be used as input to the hydrological modeling described in the SCWEPM. 


\subsection{Linkages with Human Well-Being}

\subsubsection{Human health}

Understanding environmental and ecological health is a prerequisite to protecting public health. Our goal is to use document local health information through the USGS Border Environmental Health Initiative (BEHI) and identify relationships among potential disease and environmental degradation. The BEHI project is committed to investigating linkages between the condition of the physical environment and environmental and health issues and in the west, researchers are currently studying contaminants in the SCW [61]. For example, we propose to investigate the association between temperature increases and heat stress and cardiorespiratory failure in humans; air pollution and aeroallergens with respiratory diseases (e.g., asthma), changes in water resources and vector-borne diseases (e.g., malaria, dengue, encephalitis, hantavirus, Rift Valley Fever) food shortages and human physical and mental health (e.g., malnutrition, diarrhea) [62].

\subsubsection{Environmental justice}

The U.S.-Mexico border is one of the poorest regions of the state of Arizona, with the average per capita incomes in the border counties being only $75 \%$ of the state average, and house prices at $65 \%$ of the median for the state [63]. The economic disparity between southern Arizona and the rest of the state widened over time. The 2000 Census reveals that in the rural border counties of Arizona, nearly one of five families lived in poverty, compared to one in ten throughout the nation and the state. Median family incomes in Arizona's border counties were \$34,907 in 1999, trailing the state average by more than $\$ 11,000$ and the nation by more than $\$ 15,000$. The highest levels of deprivation (e.g., housing, health care) are mostly confined to border and farmworker communities within 62 miles of the Mexican border [64]. Urbanization has contributed to this phenomenon, as fast-growing bi-national cities cannot meet demands for safe and affordable housing [65].

Colonias, a Spanish word for neighborhood, are predominantly Hispanic, poor, unplanned neighborhoods in the U.S.-Mexico borderlands that typically lack sewer, clean water, safe and sanitary housing, and other essential services, such as electricity and paved roads [66]. Colonias in the SCW demonstrate infrastructure deficiencies, poor quality housing, high levels of poverty, and a disproportionate concentration of Hispanics [63,64]. In the census tracts covering the SCW, the majority of the population is white, while $10 \%$ is Hispanic; Tucson and Nogales have higher levels of Hispanic populations (>20\%) [63]. The foreign-born presence in colonias of southern Arizona exacerbates the disconnect between people living in borderland communities and benefits from government programs, policies, and reforms [67]. Norman and others [68] identified many new colonia boundaries around Ambos Nogales, but many more exist today in the SCW and within the borderlands defined by the Cranston-Gonzales Act, in which 100 mi. radius is considered.

One of the distinguishing features of the SCWEPM is explicit consideration of the distribution of impacts in ES management. This corresponds with the Executive Order 12989, Federal Actions to Address Environmental Justice Order in Minority Populations and Low-Income Populations (1994) to investigate the environmental justice implications of environmental management. The Order directs federal agencies to develop EJ strategies and identify and address disproportionately high and adverse 
human health or environmental effects of their programs, policies, and activities on minority and low-income populations. The Order is also intended to promote nondiscrimination in federal programs substantially affecting human health and the environment. Government institutions have been reluctant to direct resources to specific borderland communities because they have no means to rank or rate communities by need [69].

Nonmarket valuation studies are a part of environmental economics, which estimate values for ES that have no clear prices, such as the value of increased biodiversity. Providing information to address overall economic inefficiency is important, and looking beyond aggregate figures can lead to more practically relevant solutions for a community. Less obvious is how environmental choices affect one group more than another. Although society could be better off as a whole, frequently some groups lose and others gain. Redistribution of wealth to make everyone better off in the new state is more stringent criteria. This is related to the well-known "pareto improvement" concept in economics, defined as any change that makes someone better off without making anyone else worse off. Relatively few environmental economists explore distribution of wealth and equity issues (for exceptions see [70]). However, decision makers care about how outcomes affect certain groups, and citizens typically care not only about their own welfare but also the welfare of those surrounding them. A more equitable approach can lead to a community with fewer class tensions and a higher quality of life. For these reasons we have decided to include EJ as explicit criteria in the SCWEPM.

The dividing influence of the International borders is especially relevant in regard to the environment [11]. Differential exposure of some populations to harmful chemicals, pesticides, and other toxins in the home, school, neighborhood, and work place are important human health factors. One goal is to identify the EJ neighborhoods in this watershed as defined by Moda [71], where 25\% or more of the population lack English language proficiency, 25\% or more of the population is foreign born, $25 \%$ or more of the population is minority, and/or median annual income of the population is at or below $65 \%$ of the state median income based on Census data and compare the distribution of environmental hazards (e.g., contaminated drinking water, decreasing water yields, etc.) in EJ communities along the border. Another goal is to generate a standardized economic valuation that incorporates spatial distribution of EJ neighborhoods with environmental hazards to provide nation-wide understanding of the ecosystem for decision-makers and potentially identify communities in need of assistance, with metrics to support them.

\subsubsection{Quality of life}

The ES related to surface water resources in this region made the river a natural focal point for residents throughout history. In the initial stages of the SCWEPM public focus groups will be held to investigate how select segments of the river are is important to the public. Ultimately the goal is to delineate the physical, social and economic attributes related to the river that are the most important to the public to be used as 'indicators' of the river resource. These attributes are by definition ES that contribute to public benefits. The SCWEPM will all draw from a riparian ecosystem 'health assessment' that is being developed for the Santa Cruz River by the Sonoran Institute as part of an EPA 'targeted watershed grant' [72]. 


\section{Approach}

The SCWEPM prototype will focus on a high-resolution analysis in the upper Santa Cruz watershed, where local water managers and city planners on both sides of the US-Mexico border are considering various water augmentation activities to circumvent social and environmental catastrophe in the face of climate change. The Ecological-Value Submodel (EVM) is the first of three components to be included in the SCWEPM and will consider the tradeoffs associated with water provisioning with models to predict impacts on habitat provisioning. Several models and data sources are being dynamically coupled in the SCWEPM prototype.

Seasonal vegetation cover and land use maps of the SCW (US-Mexico) derived from a series of three Landsat (MSS-TM) scenes (i.e., two seasons each from1976, 1987, 1996, 2006 and 2009/2010) will be compared for temporal and spatial changes in vegetation and land use. These multi-temporal land cover and land use data layers will serve as the input data layers for the Soil and Water Assessment Tool (SWAT) sub-model to predict the impacts of land use and management on water, sediment and chemical yields through time [73]. Data from rainfall gauges in the SCW will provide current and historical measurements of precipitation as input to SWAT and local stream gauge data will be used for calibration purposes.

Predicted climate change information for the SCW, derived from Intergovernmental Panel on Climate Change projections, will also be used as input to the SWAT model to examine possible changes in the watershed channel discharge, evapotranspiration, percolation, surface runoff, transmission losses, water yield, and sediment yield. In addition, future urban development and land use change maps generated by the SLEUTH model will be substituted in SWAT to identify impacts in the watershed. The Modular three-dimensional finite-difference ground-water flow model (MODFLOW) will ultimately be coupled to the SLEUTH/SWAT outputs to estimate potential future water supply based on changes in predicted infiltration rates. This will allow binational managers to identify problem areas where management activities can be focused, or to anticipate sensitive areas in association with planning efforts.

The wildlife and bird habitat for a suite of species within the SCW will be identified using the historical and current LULC maps and alternative future scenarios in relationship with the Southwest Regional Gap Analysis Project (SWReGAP) animal-models. These models are based on Wildlife Habitat Relationships (WHRs) describing resources and conditions present in areas where a species persists and reproduces or otherwise occurs [74]. Mapping alternative LULC scenarios into these models will provide estimates of habitat gained and lost for native wildlife. Preservation or conservation of cultural resources are also subject to change in climate or land use change scenarios. An important feature of the SCWEPM is the ability to identify the location of cultural resources, places of importance to past human inhabitation and development, scenic attractions, geologic features, and natural areas when considering the ramifications of natural phenomena, management practices, or both. 
Figure 6. Riparian Restoration Project site irrigated by CAP water on the SCR located at the San Xavier District of the Tohono O'odham Nation on June 26, 2009 (photo by Matt Weber with permission by TON).

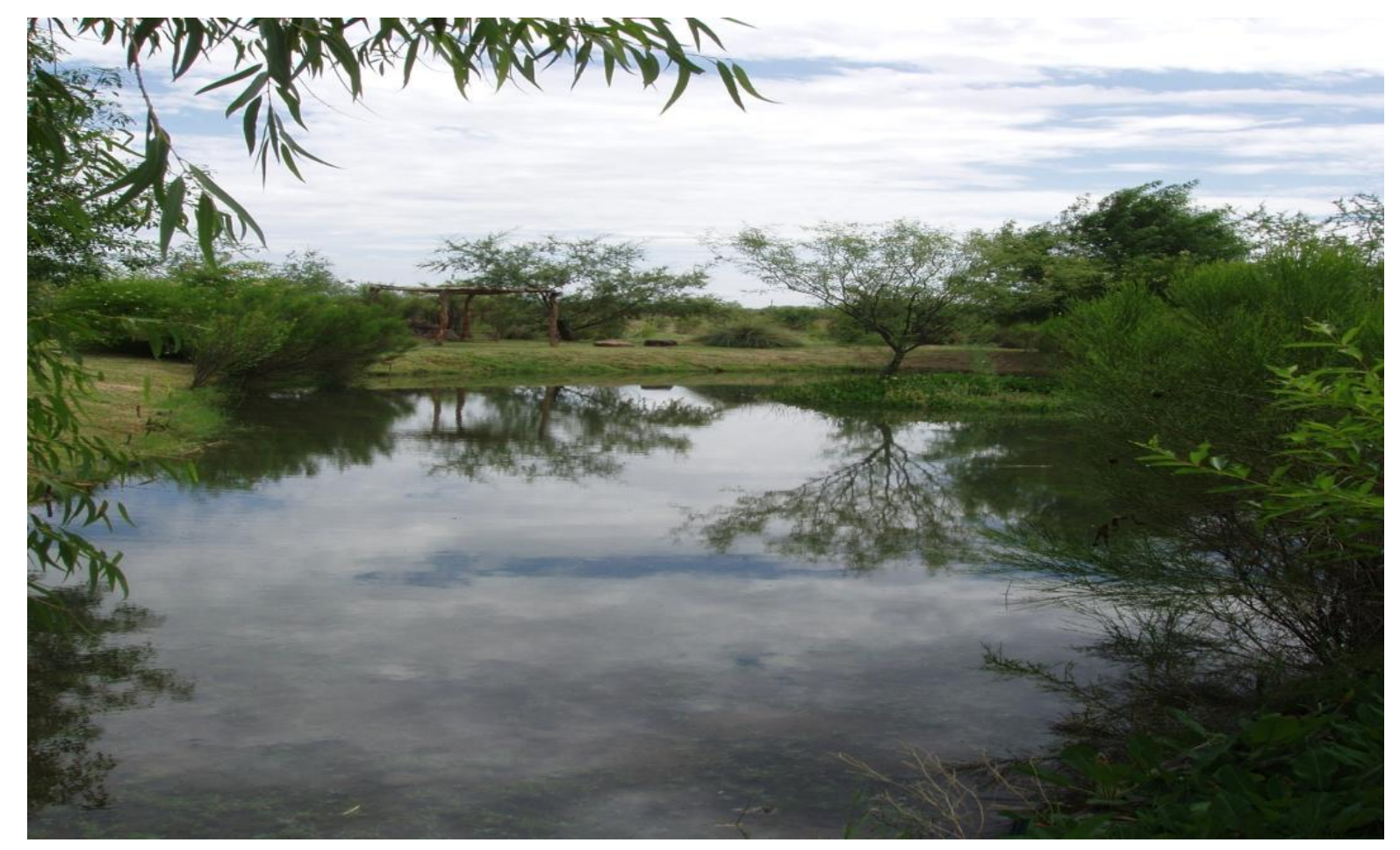

Our next step is to quantify the ecosystem services in a spatially explicit manner based on derived ecological variables and demonstrate how different scenarios will affect them. The Human-Well-Being Submodel (HWB) and the Market Land-Price Submodel (MLP) are also being developed to help identify and map the socio-cultural and economic values of goods and services provided by ecosystems.

The HWB submodel uses data and models to evaluate a set of human well-being indicators and metrics of interest to the public, land-use planners, and stakeholders. We are using information describing the political and economic history of the borderlands, documented environmental health risks, and understanding of industrialization to ascertain a quality of life. Public surveys in neighborhoods and colonias will help determine perceived quality of life, environmental health indicators, and in the future, feedback effects. A well-known deprivation index is being applied to evaluate the effects of industrialization and development on quality-of-life at the neighborhood scale, based on U.S. Census data and AGEBs (Mexican geostatistical districts) [64,75,76], and identify areas of greatest housing, social and poverty stress. We will develop a pliable layer that can demonstrate how land use change will impact people, providing an estimate of the social complexion. Those most vulnerable to changes can then be recognized and considered in community-based decision-making, in support of environmental justice.

The MLP evaluates land-price as a function of LULC patterns and other predictor variables. The MLP is based on hedonic-pricing functions, which describe each land parcel's price in terms of its particular characteristics (for example, parcel size and zoning), as well as amenities and disamenities related to location. Studies have been performed within the SCW to examine hedonics [77-79]; we will 
map such data into a geospatial layer representing relative property values that can be flexible as well to mimic impacts of land use changes.

\section{Conclusions}

There are challenges when developing a tool of this kind, especially in this International study area. Firstly, the aggregation of biophysical data across administrative boundaries is especially difficult when there are multiple resolutions and classification schemes, not to mention, languages. And secondly, approaching cultural differences without understanding can lead to miscommunication and misunderstanding. The exploration of ecological, economic, and societal affects on human well being through the ecosystem-services lens will foster cross-culture collaboration.

The identification and characterization of ecosystem services of the SCW using decades of spatial data will enable an illustrative integrated analysis of how a changing climate and land use will impact human well-being. Characterizations include the use of within-scenario predictions of ecosystem, hydrologic, and social responses. Environmental models will report results of these drivers numerically. Valuations include economic survey methods and multi-criteria decision science techniques. Combinations of results and associated values can be ranked based on relative priorities of the user.

Potential users can access the SCWEPM via the World Wide Web to explore spatially explicit changes in ecological, economic, and human well-being/quality-of-life indicator scores and attribute valuations. Users can compare alternative water management and land-use plans, evaluate proposed changes, evaluate historical trends in water management/land-use changes, and evaluate simulated/projected future changes in water supply and demand, land use, regional precipitation patterns, and other drivers. Collective information can be relayed to decision-makers to promote sustainable-resource use in consideration of a suite of ecosystem services and to allocate funding if and when necessary. The SCWEPM web interface will allow the user to explore individual value maps for each unique criterion or, after applying user-chosen multi-criteria weights, as an aggregated value map to holistically compare potential land use patterns.

Our goal is for the SCWEPM to evolve in response to management problems that surface throughout its development. It will assess the impacts of climate and land use change on the people and ecosystems of the SCW, focusing attention on those that are vulnerable to policy or management decisions. This is necessary because instream flows, stream-corridor habitat, riparian vegetation, species diversity, ground water-surface water interactions, land-use effects, climate variability, and Public Laws (e.g., the Endangered Species Act, National Historic Preservation Act), are now intertwined with water availability.

\section{Acknowledgements}

Agencies and partners who have contributed to this research agenda include the US EPA ES Research Program in the Office of Research and Development (William Kepner, Caroline Erickson, John Lin, Michael Jackson, and Don Ebert), the Sonoran Institute (Joe Marlow and Emily Brott); Arizona Department of Environmental Quality (Hans Huth and Craig Tinney); the National Park Service, Tumacacori National Historical Park (Jeremy Moss); The San Xavier District of the Tohono O'Odham Nation (Austin Nunez and Scott Rogers); Friends of the SCR (Ben Lomeli and Sherry Sass); 
Arizona State University (Francisco Lara-Valencia); The University of Arizona (Felipe Caldeira, Jill de Zapien, Mary Kay O’Rourke, Cecilia Rosales, Laura López-Hoffman, Phil Guertin, Chris Scott, Matt Skroch, Jon Cline, Angela Donelson, Adrian Esparza, and Joanna Nadeau); The Nature Conservancy (Brooke Gebow and JB Miller); and USGS colleagues (David Strong, Mark Feller, Jean Parcher, Mark Bultman, Cynthia Wallace, Kathryn Thomas, Miguel Villarreal, Ken Nussear, Rose McAndrew, Nicholas Paretti, and Diana Papoulias).

Special thanks go to Kristin Byrd and Carl Shapiro (USGS), Christopher Scott (University of Arizona), and Deborah Chaloud (U.S. EPA) and James Wickham (U.S. EPA) for their helpful reviews of this manuscript. The U.S. Environmental Protection Agency through its Office of Research and Development collaborated in the research. This manuscript has been subject to Agency peer review and approved for publication. Mention of trade names or commercial products does not constitute an endorsement or recommendation for use.

\section{References and Notes}

1. Anderson, M.T.; Woosley, L.H. Water Availability for the Western United States-Key Scientific Challenges; U.S. Geological Survey Circular 1261; USGS: Reston, VA, USA, 2005.

2. Barnett, T.; Malone, R.; Pennell, W.; Stammer, D.; Semtner, B.; Washington, W. The effects of climate change on water resources in the west: Introduction and overview. Climatic Change 2004, $62,1-11$.

3. de Groot, R.S.; Anlkemade, R.L.; Braat, L.; Hein L.; Willemen, L. Challenges in integrating the concept of ecosystem services and values in landscape planning, management and decision making. Ecol. Complex. 2009, doi:10.1016/j.ecocom.2009.10.006.

4. Wainger, L.A.; King, D.M.; Mack, R.N.; Price, E.P.; Maslin, T. Can the concept of ecosystem services be practically applied to improve natural resource management decisions? Ecol. Econ. 2010, 69, 978-987.

5. Wainger, L.A.; Price, E.W. Evaluating quality of life, economic vulnerabilities and drivers of ecosystem change. Environ. Monit. Assess. 2004, 94, 69-84.

6. Fisher, B.; Turner, R.K.; Morling, P. Defining and classifying ecosystem services for decision making. Ecol. Econ. 2009, 68, 643-653.

7. Woodard, D.; Durall, R. United States-Mexico Border Area, as Delineated by a Shared Water Resources Perspective; U.S. Department of the Interior, Field Coordinating Committee: Washington, DC, USA, 1996; Fact Sheet 1.

8. Shamir, E.; Meko, D.M.; Graham, N.E.; Georgakakos, K.P. Hydrologic model framework for water resources planning in the Santa Cruz River, Southern Arizona. J. Am. Water Resour. Assoc. 2007, 43, 1155-1170.

9. Scott, C.A.; Varady, R.G.; Browning-Aiken, A.; Sprouse, T.W. Linking water and energy along the Arizona-Sonora Border. Southwest Hydrol. 2007, 6, 26-31. 
10. Norman, L.M.; Hirsch, D.D.; Ward, A.W. Monitoring, modeling, and forecasting change within the Arizona-Sonora transboundary watersheds. In Proceedings of a USGS Workshop on Facing Tomorrow's Challenges along the U.S.-Mexico Border, Tucson, AZ, USA, 2 April 2008; U.S. Geological Survey Circular 1322; USGS: Reston, VA, USA, 2008; Available online: http://pubs.usgs.gov/circ/1322/ (accessed on 6 July 2010).

11. Ingram, H.; Varady, R.G. Empowering grassroots linkages. Arid Land. 1996, Spring/Summer, No. 39; Available online: http://ag.arizona.edu/OALS/ALN/aln39/ing\%26var.html (accessed on 6 July 2010).

12. Norman, L.M. United States-Mexican border watershed assessment: Modeling nonpoint source pollution in Ambos Nogales. J. Borderl. Stud. 2007, 22, 20.

13. Morehouse, B.J.; Ferguson, D.B.; Owen, G.; Browning-Aiken, A.; Wong-Gonzalez, P.; Pineda, N.; Varady, R. Science and socio-ecological resilience: Examples from the Arizona-Sonora Border. Environ. Sci. Policy 2008, 11, 272-284.

14. Norman, L. Urbanization and environmental degradation in Arizona Colonias. In The Colonias Reader; Esparza, A.X., Czneriak, R., Donelson, A.J., Eds.; University of Arizona Press: Tucson, AZ, USA, 2010, in press.

15. López-Hoffman, L.; Varady, R.G.; Flessa, K.W.; Balvanera, P. Ecosystem services across borders: A framework for transboundary conservation policy. Front. Ecol. Environ. 2010, 8, 84-91.

16. Labiosa, W.B.; Bernknopf, R.; Hearn, P.; Hogan, D.; Strong, D.; Pearlstine, L.; Mathie, A.M.; Wein, A.M.; Gillen, K.; Wachter, S. The South Florida Ecosystem Portfolio Model-A Map-Based Multicriteria Ecological, Economic, and Community Land-Use Planning Tool; U.S. Geological Survey Scientific Investigations Report 2009-5181; USGS: Reston, VA, USA, 2009.

17. Hassan, R.M.; Scholes, R.; Ash, N. Ecosystems and human well-being-Current state and trends-Findings of the condition and trends working group of the millennium ecosystem assessment. In The Millennium Ecosystem Assessment Series; Island Press: Washington, DC, USA, 2005; Volume 1.

18. Brody, S.D. Ecosystem Planning in Florida-Solving Regional Problems through Local Decision-Making; Ashgate: Burlington, VT, USA, 2008.

19. Peck, S. Planning for Biodiversity_Issues and Examples; Island Press: Washington, DC, USA, 1998.

20. Marsh, L.L.; Lallas, P.L. Focused, special-area conservation planning-An approach to reconciling development and environmental protection, in collaborative planning for wetlands and wildlife. In Issues and Examples; Porter, D.R., Salvesen, D.A., Eds.; Island Press: Washington, DC, USA, 1995; pp. 7-34.

21. CITYgreen; Available online: http://www.americanforests.org/productsandpubs/citygreen/ (accessed on 6 July 2010).

22. Johnson, P.; Lachman, B. Rapid Scan of Decision Support System Tools for Land-Use Related Decision Making; NatureServe: Arlington, VA, USA, 2001, unpublished; Available online: http://www.ncseonline.org/NCSSF/DSS/Documents/NatureServe/SmartPlace.doc (accessed on 6 July 2010).

23. Ecosystem-Based Management Tools Database; Available online: http://www.smartgrowthtools. org/ebmtools/index.php (accessed on 6 July 2010). 
24. Natural Capital Project Toolbox; Available online: http://www.naturalcapitalproject.org/ toolbox.html (accessed on 6 July 2010).

25. ARIES; Available online: http://esd.uvm.edu/home/introduction.html (accessed on 6 July 2010).

26. Multi-scale Integrated Models of Ecosystem Services (MIMES); Available online: http://www. uvm.edu/giee/mimes/ (accessed on 6 July 2010).

27. Muradian, R.; Kumar, P. Payment for ES and valuation-Challenges and research gaps. In Payment for ES; Kumar, P., Muradian, R., Eds.; Oxford University Press: New Delhi, India, 2009; pp. 1-16.

28. Wilson, M.A; Howarth, R.B. Discourse-based valuation of ES-Establishing fair outcomes through group deliberation. Ecol. Econ. 2002, 41, 431-443.

29. Millennium Ecosystem Assessment. Ecosystems and Human Well-being: Desertification Synthesis; World Resources Institute: Washington, DC, USA, 2005.

30. Azar, C.; Holmberg, J.; Lindgren, K. Methodological and ideological options; socio-ecological indicators for sustainability. Ecol. Econ. 1996, 18, 89-112.

31. Uhlman, K.; Guertin, D.P.; Levick, L.R.; Sprouse, T.; Westfall, E.; Holmgren, C.; Fisher, A. NEMO Watershed-Based Plan, Santa Cruz Watershed; University of Arizona: Tucson, AZ, USA, 2008.

32. Erwin, G. Groundwater Flow Model of the Santa Cruz Active Management Area Microbasins International Boundary to Nogales International Wastewater Treatment Plant Santa Cruz County, Arizona; Arizona Department of Water Resources Modeling Report No. 15; Arizona Department of Water Resources: Phoenix, AZ, USA, 2007.

33. Third Management Plan for the Santa Cruz Active Management Area, 2000-2010; Arizona Department of Water Resources: Phoenix, AZ, USA, 2000.

34. Leenhouts, J.M.; Stromberg, J.C.; Scott, R.L. Hydrologic Requirements of and Consumptive Ground-Water Use by Riparian Vegetation along the San Pedro River, Arizona; U.S. Geological Survey Scientific Investigations Report 2005-5163; U.S. Geological Survey: Reston, VA, USA, 2006.

35. Zaimes, G.; Maloney, M.L.; Rupprecht, C. Riparian areas of Arizona: Climate driven ecosystem changes, in recharge. Recharge 2007, 2, 3-7.

36. Bagstad, K.J.; Stromberg, J.C.; Lite, S.J. Response of herbaceous riparian plants to rain and flooding on the San Pedro River, Arizona, USA. Wetlands 2005, 25, 210-223.

37. Nelson, K. Groundwater Flow Model of The Santa Cruz Active Management Area along the Effluent-Dominated Santa Cruz River Santa Cruz and Pima Counties, Arizona; Arizona Department of Water Resources Modeling Report No. 14; Arizona Department of Water Resources: Phoenix, AZ, USA, 2007.

38. Central Arizona Project Homepage. http://www.cap-az.com/operations/allocations/ (accessed on 20 September 2009).

39. Peach, J.; Williams, J. Population Dynamics of the U.S.-Mexican Border Region. In SCERP Monograph; SCERP/SDSU Press: San Diego, CA, USA, 2003, unpublished; Available online: http://www.scerp.org/population.htm (accessed on 6 July 2010). 
40. Scott, C.A.; Megdal, S.; Oroz, L.A.; Callegary, J.; Vandervoet, P. Assessment of united States-México transboundary aquifers facing climate change and growth in urban water demand. Climate Res. 2010, submitted.

41. Stromberg, J.C. Fremont cottonwood-goodding willow riparian forests: A review of their ecology, threats, and recovery potential. J. Ariz.-Nev. Acad. Sci. 1993, 26, 97-110.

42. Scott, M.L.; Shafroth, P.B.; Auble, G.T. Responses of riparian cottonwoods to alluvial water table declines. Environ. Manage. 1999, 23, 347-358.

43. Patten, D.T.; Marler, R.J.; Stromberg, J.C. Assessment of the Role of Effluent-Dominated Rivers in Supporting Riparian Functions; Arizona Water Protection Fund Final Report \#95-010WP; Arizona State University: Tempe, AZ, USA, 1998.

44. Marler, R.J.; Stromberg, J.C.; Patten, D.T. Growth response of Populus fremontii, Salix gooddingii, and Tamarix ramosissima seedlings under different nitrogen and phosphorus concentrations. J. Arid Environ. 2001, 49, 133-146.

45. Brooks, B.W.; Riley, T.M.; Taylor, R.D. Water quality of effluent-dominated ecosystems: Ecotoxicological, hydrological, and management considerations. Hydrobiologia 2006, 556, 365-379.

46. Treese, S.; Meixner, T.; Hogan, J.F. Clogging of an effluent dominated semiarid river: A conceptual model of stream-aquifer interactions. JAWRA 2009, 45, 1047-1062.

47. City of Tucson; Available online: http://www.ci.tucson.az.us/agdocs/20081014/oct14-08-564a.pdf (accessed on 6 July 2010).

48. City of Portland Bureau of Planning and Sustainability. Rainwater Harvesting; Available online: http://www.portlandonline.com/bps/index.cfm?c=ecbbd\&a=bbehfa (accessed on 6 July 2010).

49. Fontaine, J.J.; van Riper, C., III. A Neotropical Migrant Bird'S Dilemma-Where to Stop for a Good Meal; U.S. Geological Survey Factsheet 2009; Available online: http://pubs.usgs.gov/fs/ 2009/30xx/ (accessed on 6 July 2010).

50. King, K.A.; Zaun, B.J.; Velasco, A.L. Contaminants as a Limiting Factor of Fish and Wildlife Populations in the Santa Cruz River, Arizona; U.S. Fish and Wildlife Service, Region 2 Contaminants Program; U.S. Fish and Wildlife Service: Phoenix, AZ, USA, 1999.

51. Norman, L.M.; Guertin, D.P.; Feller, M. A coupled-model approach to reduce nonpoint source pollution resulting from predicted urban growth: A case study in the ambos nogales watershed. J. Urban Geogr. 2008, 29, 496-516.

52. Norman, L.M.; Feller, M.; Guertin, D.P. Forecasts of Cross-border Urban Growth Using the SLEUTH Model; Ambos Nogales Watershed, United States-Mexican Border. Comput. Environ. Urban Syst. 2009, 33, 150-159.

53. Brown, C. Binational Watershed Councils as Instruments for Conflict Resolution in the Upper Santa Cruz Watershed; Udall Center Publications: Tucson, AZ, USA, 2002.

54. Smith, W. The Effects of Eastern North Pacific Tropical Cyclones on the Southwestern United States; NOAA Technical Memorandum NWS-WR-197; National Weather: Tucson, AZ, USA, 1986.

55. Hirschboeck, K.K. Climate and Floods. National Water Summary 1988-1989-Hydrologic Events and Floods and Droughts; U.S. Geological Survey Water Supply Paper 2375; USGS: Reston, VA, USA, 1991; pp. 67-88. 
56. McDonald, J.E. Variability of Precipitation in an Arid Region: A Survey of Characteristics for Arizona; Technical Reports on the Meteorology and Climatology of Arid Regions No. 1; Institute of Atmospheric Physics, University of Arizona: Tucson, AZ, USA, 1956.

57. Hirschboeck, K.K. Respecting the Drainage Divide; Water Resources Update \#126; UCOWR: Carbondale, IL, USA, 2003; Available online: http://www.ucowr.siu.edu/updates/126/index.html (accessed on 6 July 2010).

58. Hirschboeck, K.K. Flood hydroclimatology. In Flood Geomorphology; Baker, V.R., Kochel, R.C., Patton, P.C., Eds.; John Wiley \& Sons: New York, NY, USA, 1988; pp. $27-49$.

59. Webb, R.H.; Betancourt, J.L. Climatic Variability and Flood Frequency of the Santa Cruz River, Pima County, Arizona; U.S. Geological Survey Open-File Report 90-553; U.S. Geological Survey: Denver, CO, USA, 1990.

60. Serrat-Capdevila, A.; Valdes, J.B.; Gonxalez, Baird, K.; Mata, L.J.; Maddock, T. Modeling climate change impacts-And uncertainty-On the hydrology of a riparian system: The San Pedro basin (Arizona/Sonora). J. Hydrol. 2007, 347, 48-66.

61. The Border Environmental Health Initiative: Investigation of the Transboundary Upper Santa Cruz Basin; Available online: http://borderhealth.cr.usgs.gov/PDFs/WR-website.pdf (accessed on 6 July 2010).

62. Patz, J.A.; Balbus, J.M. Methods for assessing public health vulnerability to climate change. Climate Res. 1996, 6, 113-125.

63. Liverman, D.; Merideth, R.; Holdsworth, A.; Cervera, L.; Lara, F. An Assessment of the Water Resources in the San Pedro River and SCR Basins, Arizona and Sonora; A Report to the Commission on Environmental Cooperation, Montreal, Quebec; Latin American Area Center and Udall Center for Studies in Public Policy, the University of Arizona: Tucson, AZ, USA, 1997.

64. Donelson, A.J. Social Networks, Poverty and Development: An Analysis of Capacity Building in Arizona and New Mexico Colonias; Ph.D. Thesis; Department of Geography and Regional Development, University of Arizona: Tucson, AZ, USA, 2005.

65. U.S. Department of Housing and Urban Development. Delivering Results to Colonias and Farmworkers, 2005; Available online: http://www.HUD.gov (accessed on 6 July 2010).

66. Norman, L.M.; Parcher, J.W.; Lam, A.H. Monitoring Colonias along the U.S.-Mexico Border; U.S. Geological Survey Fact Sheet 2004-3070; USGS: Reston, VA, USA, 2004; Available online: http://erg.usgs.gov/isb/pubs/factsheets/fs307004.html (accessed on 6 July 2010).

67. Herzog, L. Where North Meets South: Cities, Space and Politics on the U.S. Mexico Border; Center for Mexican-American Studies: Austin, TX, USA, 1990.

68. Norman, L.M.; Donelson, A.; Pfeifer, E.; Lam, A.H. Colonia Development and Land Use Change in Ambos Nogales, United States-Mexican Border; U.S. Geological Survey Open File Report 2006-1112; USGS: Reston, VA, USA, 2006; Available online: http://pubs.usgs.gov/of/2006/1112 (accessed on 6 July 2010).

69. Presidential Documents. Federal Register 1994, 59, No. 32; Available online: http://www.dotcr.ost.dot.gov/documents/ycr/eo12898.pdf (accessed on 6 July 2010).

70. Real People, Real Environments, and Realistic Economics; Available online: http://www.e3network.org (accessed on 6 July 2010). 
71. Moda, M.A. A Critical Review of Current EJ Research: Where Do We Go from Here; Master Thesis; Clark University: Worcester, MA, USA, 2007, submitted; Available online: https://www.clarku.edu/departments/idce/docs/Moda_2007.pdf (accessed on 6 July 2010).

72. U.S. Environmental Protection Agency. Region 9: Water Program, Watershed Priorities; Available online: http://www.epa.gov/region09/water/watershed/santacruz.html (accessed on 6 July 2010).

73. Arnold, J.; Williams, A.; Srinivasan, R.; King, B.; Griggs A. SWAT, Soil and Water Assessment Tool; USDA-ARS: Temple, TX, USA, 1994.

74. USGS. Digital Animal-Habitat models for the Southwestern United States, Version 1.0.; National Gap Analysis Program; Center for Applied Spatial Ecology, New Mexico Cooperative Fish and Wildlife Research Unit, New Mexico State University: Las Cruces, NM, 2007.

75. Esparza, A.; Waldorf, B.; Chavez, J. Localized effects of globalization: The case of Ciudad Juárez, Chihuahua, Mexico. Urban Geogr. 2004, 25, 120-138.

76. Lara-Valencia, F.; Declet-Barreto, J.; Keys, E. Spatial equity and transportation hazard along cross-border trade corridors: The case of Ambos Nogales. J. Borderl. Stud. 2008, 23, 1-18.

77. Bark-Hodgins R.H.; Colby, B.G. An Economic Assessment of the Sonoran Desert Conservation Plan. Natur. Resour. J. 2006, 46, 709-725.

78. Bark-Hodgins, R.; Osgood, D.; Colby, B. Remotely sensed proxies for environmental amenities in hedonic analysis: What does green mean? In Environmental Valuation: Intraregional and Interregional Perspectives; Carruthers, J.I., Mundy, B., Eds.; Ashgate: Surrey, UK, 2008.

79. Bourne, K.L. The Effect of the Santa Cruz Riparian Corridor on Single Family Home Prices Using the Hedonic Pricing Method; Master Thesis; The University of Arizona: Tucson, AZ, USA, 2007.

(C) 2010 by the authors; licensee MDPI, Basel, Switzerland. This article is an Open Access article distributed under the terms and conditions of the Creative Commons Attribution license (http://creativecommons.org/licenses/by/3.0/). 